\title{
ANALISIS STRATEGI PENGEMBANGAN DENGAN ANALISIS SWOT SEBAGAI KAWASAN WISATA UNGGULAN DAERAH (Studi Kasus Kawasan Wisata Jumiang Kabupaten Pamekasan)
}

\author{
ANAL YSIS STUDY AND DEVELOPMENT STRATEGIES \\ WITH SWOT ANALYSIS \\ (Case Study Jumiang Area, Pamekasan Regency)
}

\author{
Yuyun Sasmita ${ }^{1}$, Campina Illa Prihantini ${ }^{*}{ }^{*}$ Nursalam $^{1}$, Musoffan $^{2}$, Darwis $^{2}$ \\ ${ }^{1}$ Universitas Sembilanbelas November Kolaka, Jalan Pemuda No. 339, Kolaka, Sulawesi \\ Tenggara \\ ${ }^{2}$ STIE Bakti Bangsa Pamekasan, Kompleks Ponpes Az-Zubair, Pamekas \\ *E-mail: campinailla26@gmail.com
}

(Diterima 09-12-2021; Disetujui 22-01-2022)

\begin{abstract}
ABSTRAK
Kawasan Wisata Jumiang merupakan salah satu objek wisata unggulan di Kabupaten Pamekasan, Jawa Timur. Kawasan ini terdiri atas pantai dan bukit yang memiliki keindahan alam yang khas. Penelitian ini menganalisis tentang strategi pengembangan kawasan wisata Jumiang sebagai wisata bahari di masa mendatang. Analisis dilakukan dengan metode analisis deksriptif kualitatif, yakni analisis SWOT. Hasil analisis menunjukkan bahwa pengembangan kawasan wisata Jumiang dapat memanfaatkan berbagai cara sesuai dengan hasil analisis SWOT yang telah dijabarkan dalam penelitian ini. Harapannya, hasil kajian dan penelitian ini dapat menjadi dasar dan bahan pertimbangan dalam pengembangan wisata edukasi yang berkelanjutan (sustainable edutourism) di Kabupaten Pamekasan, sehingga masyarakat dapat lebih mandiri dalam kehidupan ekonomi.
\end{abstract}

Kata kunci: Berkelanjutan, Strategi, Pengembangan, SWOT, Edutourism

\section{ABSTRACT}

Jumiang tourist area is a one of the top tourist attraction in Pamekasan Regency, East Java. This area consists of beaches and hills that have a distinctive natural beauty. The research analyses the development strategy of of Jumiang tourist area as a nautical tourism in the future. The analysis is conducted with a qualitative method of analysis, namely SWOT analysis. The results of the analysis showed that the development of the tourist area Jumiang can utilize various ways in accordance with the results of the SWOT analysis that has been described in this study. Hopefully, the results of this study and research can be the basis and consideration materials in the development of sustainable education tourism (sustainable edutourism) in Pamekasan District, so that the community can be more independent in economic life.

Keywords: Development, Edutourism, Strategy, SWOT, Sustainable

\section{PENDAHULUAN}

Kabupaten Pamekasan merupakan salah satu kabupaten yang terletak di antara dua kabupaten lainnya di Pulau Madura, yakni Kabupaten Sampang dan Kabupaten Sumenep. Dibandingkan tiga kabupaten lainnya, Kabupaten Pamekasan hanya memiliki beberapa objek wisata unggulan, misalnya Pantai Jumiang, Pantai Talang Siring, 


\section{ANALISIS STRATEGI PENGEMBANGAN DENGAN ANALISIS SWOT \\ SEBAGAI KAWASAN WISATA UNGGULAN DAERAH \\ Yuyun Sasmita, Campina Illa Prihantini, Nursalam, Musoffan, dan Darwis}

Kawasan Wisata Batik, dan Wisata Religi Batumarmar. Beberapa waktu terakhir, objek wisata di Kabupaten Pamekasan bertambah, misalnya Wisata Selamat Pagi Madura dan Brukoh Hills.

Seiring dengan meningkatnya jumlah penduduk dan wisatawan yang datang berkunjung ke Pulau Madura, terjadi peningkatan permintaan wisata sebagai kebutuhan sekunder. Bahkan saat ini, berwisata atau rekreasi telah berubah sifatnya menjadi kebutuhan primer, terlebih bagi masyarakat milineal (Umam, 2015). Masyarakat yang tinggal di wilayah perkotaan membutuhkan kegiatan wisata untuk menghilangkan kejenuhan dan kepenatan setelah melakukan aktifitas sehari-hari yang melelahkan di perkotaan. Tuntutan kerja yang dialami serta gaya hidup yang dianut oleh masyarakat perkotaan menuntut mereka untuk melakukan kegiatan wisata di akhir pekan untuk beristirahat sejenak. Kenyataan ini tidak menutup kemungkinan bahwa masyarakat pedesaan juga membutuhkan kegiatan wisata, karena mereka juga membutuhkan sarana untuk meninggalkan rutinitas sehari-hari sementara waktu. Alasan-alasan diatas termasuk ke dalam salah satu motivasi yang dimiliki oleh seorang wisatawan ketika melakukan kegiatan wisata (Yoeti, 2010).

Peningkatan permintaan terhadap rekreasi atau wisata tentu harus disambut positif oleh berbagai pihak, baik pemerintah setempat ataupun pengelola objek wisata. Terlebih, adanya kunjungan dari wisatawan terhadap suatu objek wisata juga memberikan kontribusi nyata terhadap devisa negara (BPS, 2013).

Berkaitan dengan hal tersebut, peningkatan dan pengembangan wisata lokal juga harus terus dilakukan. Salah satunya adalah terhadap Pantai Jumiang. Pantai Jumiang merupakan objek wisata unggulan di Kabupaten Pamekasan (BPS, 2018). Pada beberapa tahun yang silam, Pantai Jumiang mulai dilupakan oleh wisatawan lokal. Hal ini dikarenakan terbatasnya atraksi wisata yang terdapat di pantai ini. Selain itu, kondisi fasilitas wisata juga kurang mendukung. Hal ini tentu memengaruhi jumlah kunjungan wisatawan. Padahal, potensi yang dimiliki oleh Pantai Jumiang cukup memadai. Pemandangan alam yang langsung menghadap Selat Madura merupakan kekhasan Pantai Jumiang. Akhirnya, dua tahun terakhir, pengelola Pantai Jumiang melakukan pembenahan. Penambahan atraksi wisata, seperti Banana Boat dan Penyemaian bibit rumput laut menjadi primadona bagi wisatawan. Selain itu, pengadaan Gazebo dan beberapa spot swafoto juga menjadi nilai tambah bagi Pantai Jumiang. Pembenahan 
yang dilakukan oleh Dinas Pariwisata dan pengelola Pantai Jumiang ternyata berdampak positif. Jumlah kunjungan mengalami peningkatan semenjak adanya penambahan atraksi dan fasilitas wisata di Pantai Jumiang.

Permasalahan yang dihadapi oleh pengelola Pantai Jumiang dipengaruhi oleh beberapa faktor. Pertama, kurangnya sinkronisasi antara Dinas Pariwisata Kabupaten Pamekasan dan pengeloala Pantai Jumiang. Hal ini terlihat seolah-olah pengelola berjalan dengan sendiri tanpa dukungan dari pemerintah setempat. Kedua, kurangnya partisipasi masyarakat di sekitar Pantai Jumiang dalam upaya pengembangan wisata Pantai Jumiang. Hal ini sangat disayangkan. Padahal masyarakat sekitar dapat diberdayakan sebagai pemandu wisata dan semacamnya. Ketiga, kurangnya minat masyarakat Kabupaten Pamekasan dalam mempromosikan Pantai Jumiang. Hal ini disebabkan karena kondisi Pantai Jumiang yang kurang tertata dan terurus, sehingga minat kaula muda untuk mempromosikan menjadi berkurang. Analisis kelembagaan dan perspesi wisatawan terhadap atraksi dan fasilitas wisata di Pantai Jumiang sangat perlu dilakukan. Hal ini bertujuan agar Pemerintah Kabupaten Pamekasan dan pengelola Pantai Jumiang dapat terus mengevaluasi diri dalam melakukan pengembangan wisata lokal. Dengan demikian, tujuan untuk menjadikan Pantai Jumiang sebagai wisata yang berkelanjutan (sustainable tourism) dapat tercapai. Tujuan utama dalam penelitian ini adalah untuk menganalisis strategi pengembangan wisata Jumiang.

\section{METODE PENELITIAN}

Penilitian ini dilakukan di Pantai Jumiang yang terletak di Kecamatan Pademawu, Kabupate Pamekasan, Jawa Timur. Pemilihan lokasi dilakukan secara sengaja (purposive) dengan pertimbangan bahwa Pantai Jumiang memiliki potensi untuk dikembangkan sebagai objek wisata lokal. Penelitian ini dilaksanakan selama enam bulan. Data yang digunakan dalam penelitian ini adalah data primer dan data sekunder. Data primer diperoleh dari wawancara langsung dalam kuesioner kepada responden. Data sekunder yang dibutuhkan dalam penelitian ini yaitu data-data yang terkait dengan daerah penelitian dan data lainnya yang dibutuhkan di dalam penelitian ini. Data ini diperoleh dari instansi terkait, berbagai pustaka seperti buku, jurnal, dan internet.

Metode pengambilan contoh dalam penelitian ini dilakukan secara stratified random sampling yaitu responden dipilih berdasarkan asal wisatawan, wisatawan 
domestik dari dalam Pamekasan atau wisatawan domestik dari luar Pamekasan. Selain itu, penelitian ini juga menggunakan snowball sampling. Metode ini diterapkan dalam pengambilan data sekunder dan wawancara dengan narasumber yang kompeten sesuai dengan informasi yang dibutuhkan oleh peneliti. Jumlah responden yang diambil untuk melakukan penelitian ini sebanyak 100 responden dimana 50 reponden untuk wisatawan domestik dari dalam Pamekasan dan 50 responden untuk wisatawan domestik dari luar Pamekasan. Sedangkan untuk wawancara persepsi kelembagaan pengelola Pantai Jumiang, jumlah responden yang digunakan disesuaikan dengan jumlah petugas dan karyawan yang tergabung sebagai pengelola Pantai Jumiang.

\section{Analisis SWOT Sebagai Strategi Pengembangan Wisata Jumiang}

Tabel 1 Contoh Analisa SWOT

\begin{tabular}{lll}
\hline \multicolumn{1}{c}{ Analisis Internal } & Kekuatan (s) & Kelemahan (w) \\
Analisis Eksternal & Faktor-faktor kekuatan & Faktor-faktor kelemahan \\
\hline Peluang (o) & S- O Strategi & W- O Strategi \\
Faktor-faktor Peluang & Gunakan kekuatan untuk & $\begin{array}{l}\text { Minimalkan kelemahan untuk } \\
\text { memanfaatkan peluang }\end{array}$ \\
& memanfaatkan peluag & W-T Strategi \\
Ancaman (T) & S-T Strategi & Meminimalkan kelemahan dan \\
Faktor-faktor Ancaman & Gunakan kekuatan untuk & menghindari ancaman \\
& Menghindari ancaman &
\end{tabular}

Sumber : (Rangkuti. 2004)

Pada analisis ini peneliti menggunakan Matriks SWOT seperti yang tertera dalam Tabel 1. Matriks SWOT (Strengths, Weaknesses, Oppurtunities, Threats) didasarkan pada logika yang dapat memaksimalkan kekuatan (Strengths) dan peluang (Oppurtinities), namun secara bersamaan dapat meminimalkan kelemahan (Weaknesses) dan ancaman (Threats) (Rangkuti, 2004; Saghaei et al, 2012). Matriks SWOT merupakan matching tool yang penting untuk membantu mengembangkan empat tipe strategi. Keempat strategi tersebut ialah :

\section{a) Strategi SO (Strength - Opportunity)}

Strategi ini menggunakan kekuatan internal pengelolaan Pantai Jumiang untuk meraih peluang-peluang yang ada di luar pengelolaan Pantai Jumiang. Jika pengelolaan Pantai Jumiang memiliki banyak kelemahan, maka pihak pengelola Pantai Jumiang harus mengatasi kelemahan itu agar menjadi sebuah kekuatan, dan sebaliknya.

\section{b) Strategi WO (Weakness - Opportunity)}

Strategi ini bertujuan untuk memperkecil kelemahan-kelemahan internal yang ada di pengelolaan Pantai Jumiang dengan memanfaatkan peluang-peluang eksternal. 
Strategi ini sangat berguna ketika pihak pengelola Pantai Jumiang mengalami kesulitan untuk memanfaatkan peluang-peluang yang ada dikarenakan adanya kelemahankelemahan internal.

\section{c) Strategi ST (Strength - Threat)}

Melalui strategi ini, pihak pengelola Pantai Jumiang berusaha untuk menghindari atau mengurangi dampak dari ancaman-ancaman eksternal. Misal ancaman dari lahirnya kawasan-kawasan wisata baru yang dapat mengurangi minat para wisatawan untuk berkunjung ke Pantai Jumiang.

\section{d) Strategi WT (Weakness - Threat)}

Strategi ini merupakan strategi untuk bertahan dengan cara mengurangi kelemahan internal serta menghindari ancaman. Suatu kelembagaan seperti pengelolaan Pantai Jumiang yang dihadapkan pada sejumlah kelemahan internal dan ancaman eksternal berada dalam posisi yang berbahaya. Oleh sebab itu strategi ini dibutuhkan untuk dapat mengurangi kelemahan internal pengelolaan Pantai Jumiang serta menghindari ancaman eksternal.

\section{HASIL DAN PEMBAHASAN}

\section{Karakteristik Wisatawan}

Karakteristik wisatawan pada penelitian ini didapat dari hasil wawancara dengan wisatawan yang datang ke kawasan wisata Jumiang. Jumlah wisatawan yang menjadi responden dalam penelitian ini ialah 100 wisatawan. Hal ini dilakukan untuk mengetahui macam-macam karakter wisatawan dan untuk mengetahu perspesi mereka terhadap kondisi sarana dan prsarana, atraksi wisata, dan fasilitas yang ada di kawasan wisata Jumiang. Berikut beberapa kriteria yang dapat menjelaskan karakteristik wisatawan yang berkunjung ke kawasan wisata Jumiang:

(1) Jenis Kelamin

Wisatawan yang berkunjung ke Kawasan wisata Jumiang pada umumnya adalah wisatawan rombongan, baik itu rombongan keluarga maupun rombongan lainnya. Persentase menunjukkan sebanyak $57 \%$ atau 57 orang pengunjung Kawasan wisata Jumiang adalah laki-laki. Sisanya sebanyak $43 \%$ atau 43 orang berjenis kelamin perempuan. Persentase perbandingan jenis kelamin ini dapat dilihat pada Gambar 1 dibawah ini. Persentase ini tidak menunjukkan bahwa wisatawan yang berkunjung ke 
Kawasan wisata Jumiang didominasi oleh laki-laki. Hanya saja laki-laki memiliki pengaruh lebih tinggi dibandingkan perempuan dalam mengambil keputusan diantara anggota rombongan yang lainnya. Wisatawan yang berkunjung ke Kawasan wisata Jumiang pada umumnya adalah wisatawan rombongan, baik itu rombongan keluarga maupun rombongan lainnya. Persentase menunjukkan sebanyak 57\% atau 57 orang pengunjung Kawasan wisata Jumiang adalah laki-laki. Sisanya sebanyak 43\% atau 43 orang berjenis kelamin perempuan. Persentase perbandingan jenis kelamin ini dapat dilihat pada Gambar 1 dibawah ini. Persentase ini tidak menunjukkan bahwa wisatawan yang berkunjung ke Kawasan wisata Jumiang didominasi oleh laki-laki. Hanya saja laki-laki memiliki pengaruh lebih tinggi dibandingkan perempuan dalam mengambil keputusan diantara anggota rombongan yang lainnya.

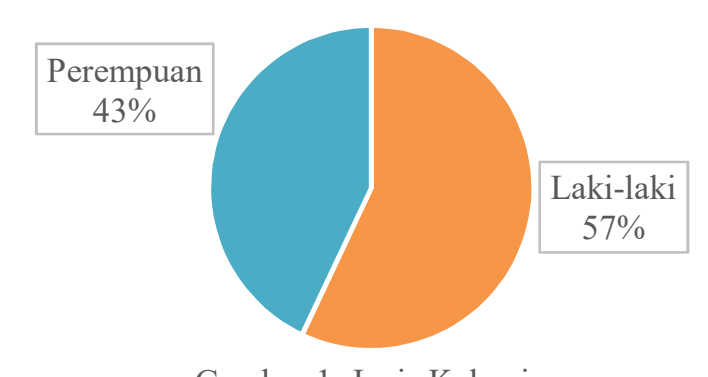

Gambar 1. Jenis Kelamin

Sumber: Data primer, diolah (2019)

(2) Usia

Karakterisitk usia wisatawan yang berkunjung ke Kawasan wisata Jumiang didominasi oleh kategori umur $<17$ tahun dengan persentase $30 \%$ atau sebanyak 30 orang. Kemudian kategori umur 17-55 tahun dengan persentase 54\% atau sebanyak 54 orang. Kategori umur $>55$ tahun berada di urutan ketiga dengan persentase $16 \%$ atau berjumlah 16 orang. Tingginya persentasi kategori umur $<17$ tahun menunjukkan bahwa wisatawan Kawasan Wisata Jumiang adalah remaja, tingkat Sekolah Menengah. Persentase karakteristik responden berdasarkan usianya bisa dilihat pada Gambar 2. 


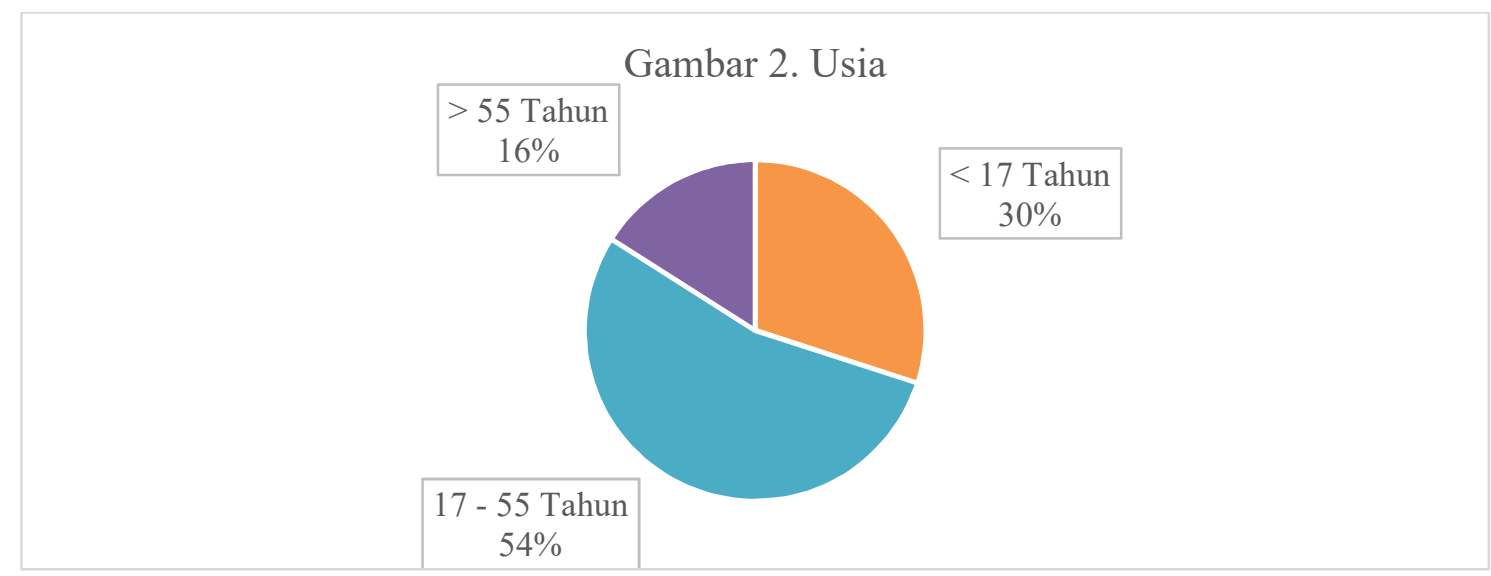

Sumber: Data primer, diolah (2019)

(3) Pekerjaan

Pekerjaan para wisatawan yang berkunjung ke Kawasan wisata Jumiang didominasi oleh para pelajar atau siswa dengan persentase $32 \%$ atau 32 orang. Selanjutnya wisatawan yang bekerja sebagai wiraswasta dengan persentase $30 \%$ atau berjumlah 30 orang. Dilanjutkan oleh para ibu rumah tangga dengan persentase $27 \%$ atau 27 orang. Terakhir adalah wisatawan dengan pekerjaan PNS memiliki persentaase $11 \%$ atau berjumlah 11 orang. Perbandingan jenis pekerjaan para wisatawan dapat dilihat pada Gambar 3.

\section{Gambar 3 Karakteristik Responden Berdasar Pekerjaan}

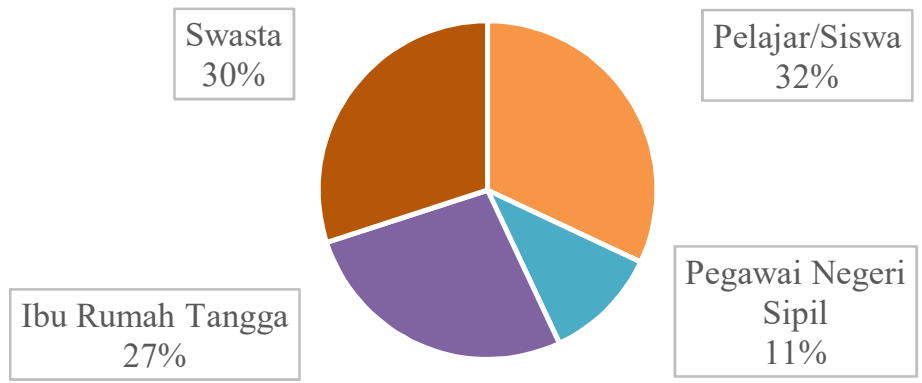

Sumber: Data primer, diolah (2019)

(4) Tingkat Pendidikan Terakhir

Tingkat pendidikan para wisatawan didominasi oleh lulusan SMA dengan persentase $45 \%$ atau 45 orang. Lalu disusul oleh wisatawan dengan lulusan D3/S1/S2 dengan persentase $28 \%$ atau 28 orang. Sisanya adalah lulusan SD berjumlah 27 orang dengan persentase $27 \%$. Persentase tingkat pendidikan wisatawan dapat dilihat pada Gambar 4 dibawah ini. 
Gambar 4 Karakteristik Responden Berdasar Pendidikan Terakhir

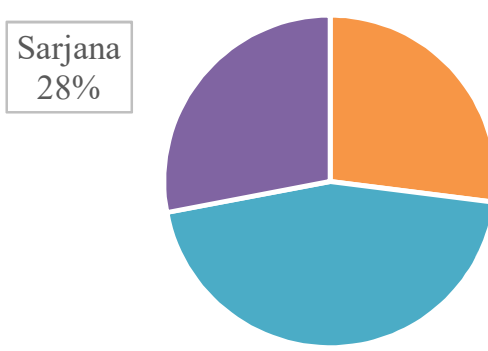

Sumber: Data primer, diolah (2019)

(5) Pendapatan

Pendapatan wisatawan dapat dilihat dari jenis pekerjaan setiap wisatawan yang datang. Wisatawan yang datang berkunjung menyatakan bahwa pendapatan yang berada dalam kategori $<\operatorname{Rp} 1.500 .000$ adalah sejumlah $49 \%$ atau 49 orang. Hal ini dikarenakan sebagian besar wisatawan yang datang adalah siswa atau pelajar yang mana memang belum memiliki pekerjaan utama. Urutan kedua adalah kategori wisatawan yang memiliki pendapatan Rp 1.500.000 - Rp 3.000.000 dengan persentase 33\% atau 33 orang. Kategori ini pada umumnya adalah wisatawan dengan pekerjaan swasta dan ibu rumah tangga. Urutan terakhir adalah kategori pendapatan $>$ Rp 3.000 .000 dengan persentase $18 \%$ atau 18 orang. Perbandingan kategori pendapatan wisatawan disajikan dalam Gambar 5.

\section{Gambar 5 Karakteristik Responden Berdasar Pendapatan}

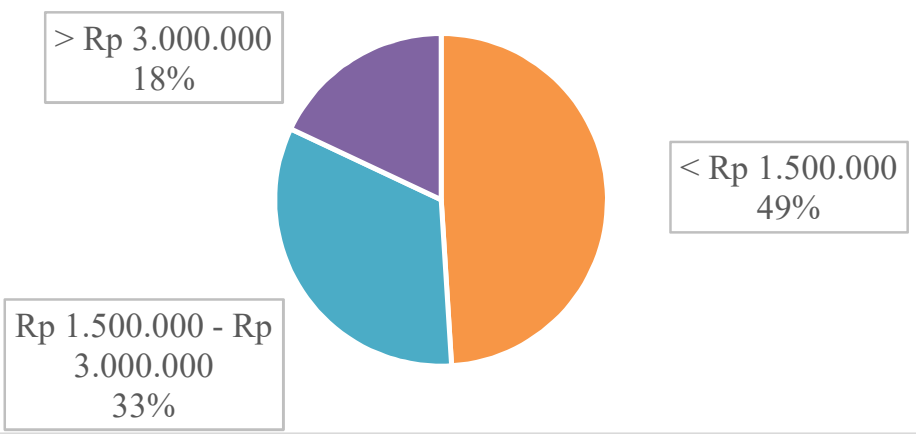

Sumber: Data primer, diolah (2019)

(6) Asal Daerah

Disebabkan tempat wisata yang cukup jauh dari pusat kota Pamekasan dan akses yang masih kurang begitu baik, pengunjung masih ramai didatangi oleh $79 \%$ responden 
yang berasal dari dalam Kabupaten Pamekasan. Sedangkan sisanya, sejumlah $21 \%$ atau 21 orang berasal dari luar Kabupaten Pamekasan, seperti Kabupaten Sampang dan Kabupaten Sumenep.

Gambar 6 Karakteristik Responden Berdasar Asal Daerah

\begin{tabular}{|c|}
\hline Luar Kota \\
$21 \%$ \\
\hline
\end{tabular}

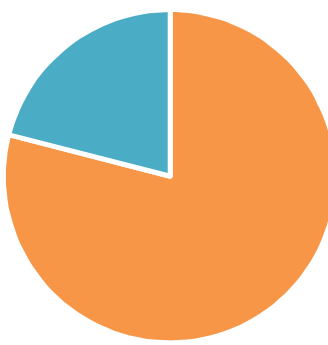

Dalam Kota $79 \%$

Sumber: Data primer, diolah (2019)

(7) Jumlah Tanggungan

Persentase jumlah tanggungan wisatawan yang berkunjung ke Kawasan wisata Jumiang didominasi oleh wisatawan yang memiliki tanggungan keluarga sebanyak 1-3 orang dengan persentase $43 \%$ atau berjumlah 43 orang. Lalu, wisatawan yang belum memiliki tanggungan keluarga dengan persentase 32\% atau berjumlah 32 orang. Kategori adalah wisatawan yang merupakan siswa atau pelajar. Selanjutnya, wisatawan dengan jumlah tanggungan 3-6 orang memiliki persentase sebesar $20 \%$ atau berjumlah 20 orang. Sisanya adalah wisatawan dengan jumlah tanggungan diatas 6 orang dengan persentase $5 \%$ atau berjumlah lima orang. Jumlah tanggungan ini berdasarkan pada jumlah tanggungan keluarga inti yaitu istri, anak dan orang tua yang biaya hidupnya ditanggung oleh wisatawan. Persentase karakteristik wisatawan berdasarkan jumlah tanggungan dapat dilihat pada Tabel 7.

Gambar 7 Karakteristik Responden Berdasar Jumlah Tanggungan Keluarga

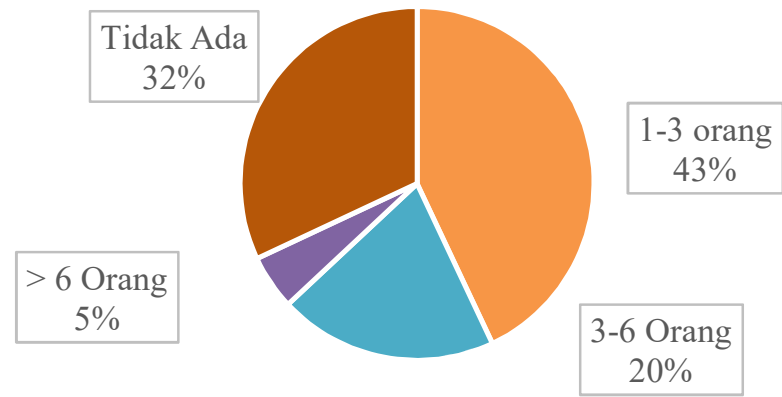

Sumber: Data primer, diolah (2019) 


\section{Analisis dan Perancangan Strategi Pengembangan dengan SWOT}

Berdasarkan identifikasi terhadap lingkungan internal pengelolaan Kawasan wisata Jumiang dan hasil wawancara dengan key person yang berperan terhadap pengembangan Kawasan wisata Jumiang, diperoleh beberapa faktor internal yang berpengaruh terhadap pengembangan Kawasan wisata Jumiang. Faktor-faktor internal yang berpengaruh terhadap pengembangan Kawasan wisata Jumiang dapat dilihat pada Tabel 2. Tabel tersebut menunjukkan bahwa ada 10 faktor yang berpengaruh langsung dalam pengembangan Kawasan wisata Jumiang.

\section{Strategi Strength - Opportunities (SO)}

Strategi ini mengkombinasikan antara kekuatan yang dimiliki dengan peluang yang ada. Berdasarkan Tabel 9, diperoleh lima alternatif strategi SO. Strategi SO yang pertama (S1O2) adalah menambah wahana yang lebih menarik dengan panorama yang ada. Strategi ini diperoleh dari kombinasi faktor kekuatan yaitu, panorama alam yang indah dengan suasana pantai dan laut (S1) dengan faktor peluang yakni masih terdapat beberapa lahan untuk pengembangan (O2). Strategi ini bertujuan untuk memaksimalkan atraksi serta alur wisata yang telah ada dengan memanfaatkan sumberdaya yang ada. Hal ini perlu didukung oleh kebijakan pemerintah daerah untuk meningkatkan jumlah kunjungan wisata ke Kabupaten Pamekasan pada umumnya dan Kawasan Wisata Jumiang pada khususnya. Strategi ini sangat tepat diterapkan dengan memanfaatkan isu yang sedang berkembang baik mengenai wisata alam dan disebarluaskan pada acaraacara yang akan diadakan oleh Pemerintah Daerah Kabupaten Pamekasan.

Strategi SO yang kedua (S2O1) ialah mengembangkan komoditas khas menjadi produk unggulan kreatif. Alternatif strategi ini merupakan perpaduan dari faktor kekuatan yaitu mempunyai komoditas khas yang unik (S2) dan berpeluang menjadi destinasi wisata populer (O1). Strategi ini bertujuan untuk menciptakan sebuah acara baru yang dapat dilaksanakan di Kawasan Wisata Jumiang dengan mengandalkan semua sumberdaya serta atraksi wisata yang ada dan didukung oleh pemerintah daerah. Sehingga acara ini dapat tersebar luas di kalangan wisatawan dan dapat meningkatkan daya tarik wisatawan untuk dapat berkunjung ke Kawasan Wisata Jumiang. 
Strategi SO yang ketiga (S3O1) adalah meningktkan kualitas wahana photospot. Alternatif strategi ini adalah kombinasi kekuatan wahana photospot yang menarik (S3) dan peluang berpeluang menjadi destinasi wisata populer (O1). Akhir-akhir ini, swafoto atau selfie sudah semakin populer, terlebih untuk kalangan anak muda. Wisatawan Jumiang pada umumnya adalah anak muda, hal ini merupakan peluang yang cukup besar untuk diamnfaatkan, salah satunya adalah dengan menambah kualitas wahana photospot. Peningkatan kualitas wahana photospot diharapkan dapat meningkatkan popularitas kawasan wisata Jumiang di kalangan anak muda.

Strategi SO yang keempat (S4O3) adalah meningkatkan promosi yang lebih menarik bersama dengan masyarakat. Alternatif strategi ini adalah kombinasi kekuatan yakni jarak yang tidak terlalu jauh dari jalan raya (S4) dengan faktor peluang, yakni mempunyai respon positif dari masyarakat (O3). Strategi ini bertujuan untuk memanfaatkan dukungan masyarakat yang tinggi terhadap pengembangan kawasan wisata Jumiang, salah satunya adalah Kelompok Sadar Wisata (Pok-Darwis) kawasan wisata Jumiang, Selain itu, terdapat pula Kelompok Tani Rumput Laut yang pada umumnya adalah ibu rumah tangga. Tingginya dukungan masyarakat terhadap kemajuan kawasan wisata Jumiang diharapkan juga mendapat dukungan dari pemerintah daerah Kabupaten Pamekasan. Pemberian pelatihan kepada anggota PokDarwis dan kelompok tani rumput laut merupakan salah satu dukungan nyata dari pemerintah daerah. Jika dua pihak saling berkolaborasi dalam upaya pengembangan kawasan wistaa Jumiang, tujuan pembentukan wisata edukasi berkelanjutan (sustainable edutourism) dapat tercapai.

Strategi SO yang terakhir (S5, O1, O3) adalah memunculkan sejarah lokal pada publik. Alternatif strategi ini adalah kombinasi kekuatan merupakan destinasi yang bersejarah lokal (S5) dengan faktor peluang yakni berpeluang menjadi destinasi wisata populer (O1) dan peluang mempunyai respon positif dari masyarakat (O3). Strategi ini bertujuan untuk meningkatkan popularitas destinasi wisata bersejarah lokal yang ada di kawasan wisata Jumiang, yakni Makam Adirasa. Pengembangan wisata religi juga menjadi salah satu wisata populer. Dengan keberadaan Makam Adirasa di kawasan wisata Jumiang, pilihan destinasi menjadi beragam. Selain untuk menjaga kelestarian lingkungan juga menjaga kelestarian wisata bersejarah lokal.

\section{Strategi Strength - Threats (ST)}




\section{ANALISIS STRATEGI PENGEMBANGAN DENGAN ANALISIS SWOT \\ SEBAGAI KAWASAN WISATA UNGGULAN DAERAH \\ Yuyun Sasmita, Campina Illa Prihantini, Nursalam, Musoffan, dan Darwis}

Strategi ini akan memadukan faktor kekuatan dengan faktor ancaman yang dimiliki. Sehingga diharapkan dapat mengurangi pengaruh ancaman-ancaman yang dimiliki. Alternatif strategi ST yang pertama (S1S2S3T1) adalah meningkatkan kualitas wisata dengan keunikan panorama, photospot dan komoditas yang dapat dijadikan sebagai ikon wisata. Alternatif strategi ini merupakan hasil perpaduan dari beberapa faktor kekuatan yaitu panorama alam yang indah dengan suasana pantai (S1), mempunyai komoditas khas yang unik (S2), dan wahana photospot yang menarik (S3) dipadukan dengan faktor ancaman yaitu adanya wisata sejenis di dalam satu kabupaten (T1). Strategi ini bertujuan untuk menciptakan sebuah atraksi wisata yang dapat meminimalisir persaingan dengan objek wisata lainnya, lebih sesuai dengan tingkat pendapatan wisatawan. Perlu diakui bahwa perkembangan destinasi wisata di Kabupaten Pamekasan cukup cepat. Namun pada umumnya memang berupa wisata alam. Kawasan wisata Jumiang yang memang memiliki potensi dan peluang yang besar untuk dikembangkan, rasa-rasanya mampu bersaing dengan destinasi wisata lainnya yang masih baru. Pembuatan atraksi wisata baru yang sesuai untuk dikembangkan contohnya adalah permainan outbond alam bebas. Menciptakan atraksi baru dapat dilakukan dengan bekerjasama dengan pihak luar (mitra) yang profesional dalam bidang ini.

Alternatif strategi ST yang kedua (S4T2) adalah melakukan komunikasi dengan pemerintah setempat untuk mengintegrasi regulasi yang baik. Strategi ini merupakan hasil perpaduan antara faktor kekuatan yaitu jarak yang tidak terlalu jauh dari jalan raya (S4) dipadukan dengan faktor ancaman yaitu regulasi setempat belum terintegrasi dengan baik (T2). Strategi ini bertujuan untuk menyinkronkan antara lembaga yang di bawah, yakni pengelola (Pok-Darwis), dengan lembaga yang lebih tinggi, yakni Pemerintah Desa Tanjung dan Dinas Priwisata Kabupaten Pamekasan. Selama ini, sistem pengelolaan kawasan wisata Jumiang masih belum optimal. Terlebih masih ada aturan yang tumpang tindih, salah satunya adalah upaya perbaikan jalan dan akses menuju kawasan wisata ini. Dukungan dari pemerintah daerah sangatlah dibutuhkan. Karena berdsarkan hasil wawancara dengan Ketua Pok-Darwis, mereka cenderung 'berjalan sendiri' dalam mengupayakan perbaikan jalan dan akses menuju kawasan wisata. 
Alternatif strategi ST yang terakhir (S5T3) adalah memperbaiki manajemen PokDarwis karena masih berbudaya lokal. Strategi ini merupakan hasil perpaduan antara faktor kekuatan yaitu merupakan destinasi yang bersejarah lokal (S5) dipadukan dengan faktor ancaman yaitu manajemen Pok-Darwis yang masih tidak stabil (T3). Berdasarkan cerita dari Ketua Pok-Darwis, terbentuknya Pok-Darwis adalah rekomendasi dari Pemerintah Desa Tanjung. Pemilihan anggota hanya berdasarkan kekerabatan dan tidak dipilih berdasarkan kapasitas yang dimiliki. Akibatnya, banyak anggota Pok-Darwis yang tidak melaksanakan kewajibannya sebagai anggota. Hal ini sangat disayangkan karena pada beberapa kesempatan, Dinas Pariwisata Kabupaten Pamekasan memberikan kesempatan Pok-Darwis untuk mengikuti pelatihan pengembangan wisata. Selain itu, manajemen Pok-Darwis masih dikatakan tidak stabil karena anggota masih kurang kesadarannya. Oleh karena itu, pemerintah perlu ikut sera agar manajemen PokDarwis lebih baik. Kegiatan pelatihan kepada anggota Pok-Darwis dari dinas terkait diharapkan dapat terlaksana. Pemerintah daerah dan dinas terkait dapat memfasilitasi kegiatan ini melalui penyediaan narasumber yang profesional. Sehingga diharapkan dapat menghasilkan pemahaman yang baik bagi para karyawan mengenai sistem kelembagaan. Setelah mengikuti kegiatan ini diharapkan para anggota bisa lebih mengerti mengenai sistem kelembagaan pengelolaan Kawasan wisata Jumiang. Tujuan akhir strategi ini ialah meningkatkan daya tarik wisatawan untuk berkunjung ke Kawasan Wisata Jumiang.

\section{Strategi Weakness - Opportunities (WO)}

Strategi ini merupakan perpaduan dari faktor kelemahan dan peluang yang dimiliki. Sehingga diharapkan kelemahan-kelemahan yang dimiliki dapat tertutupi dengan keberadaan peluang yang dimiliki. Strategi WO yang pertama (W1O2) adalah redesign tata letak wisata. Alternatif strategi ini merupakan perpaduan dari faktor kelemahan yaitu tata letak destinasi wisata belum rapi (W1) dengan faktor peluang yaitu masih ada beberapa lahan untuk pengembangan (O2). Strategi ini bertujuan untuk memperbaiki tata letak wisata yang lebih baik dan teratur sehingga wisatawan yang datang dapat menikmati pemandangan alam yang ada di kawasan wisata ini. Beberapa lahan yang belum dimanfaatkan secara optimal adalah lahan parkir. Wisatawan pada umumnya membawa mobil mereka berdekatan dengan saung tempat mereka akan bersantai. Hal ini membuat lahan parkir tidak dimanfaatkan secara optimal dan 


\section{ANALISIS STRATEGI PENGEMBANGAN DENGAN ANALISIS SWOT \\ SEBAGAI KAWASAN WISATA UNGGULAN DAERAH \\ Yuyun Sasmita, Campina Illa Prihantini, Nursalam, Musoffan, dan Darwis}

berdampak pada pemdangan mobil dan motor yang amburadul. Melakukan redesign tata letak destinasi wisata, harapannya lahan parkir dapat dimanfaatkan sehingga tidak mengganggu pemandangan alam yang memang menjadi modal utama bagi kawasan wisata Jumiang.

Strategi WO yang kedua (W2O3) adalah meningktkan kebersihan lingkungan. Strategi ini merupakan perpaduan antara faktor kelemahan yaitu kebersihan lingkungan kurang optimal (W2) dengan faktor peluang yaitu mempunyai respon positif dari masyarakat (O3). Strategi ini bertujuan untuk memperbaiki kebersihan lingkungan yang selama ini masih dipandang rendah. Tingkat kesadaran wisatawan dan para pedagang kios makanan masih dikatakan rendah. Padahal tempat sampah telah banyak disediakan. Hanya saja, kawasan ini belum memiliki Tempat Pembuangan Akhir (TPA). Harapannya, pemerintah desa turut memberikan solusi agar tersedia TPA. Selain itu, perlu dibuatkan aturan tertulis agar wisatawan dan pemilik kios makanan untuk membuang sampah pada tempatnya. Sehingga permasalahan kebersihan lingkungan dapat teratasi.

Strategi WO yang terakhir (W2, O1, O2) adalah menambah sarana dan prasarana yang dibutuhkan. Alternatif strategi ini adalah kombinasi kekuatan kebersihan lingkungan kurang optimal (W2), berpeluang menjadi destinasi wisata populer (O1), dan masih ada beberapa lahan untuk pengembangan (O2). Strategi ini bertujuan akhir menambah jumlah wisatawan yang akan berkunjung ke kawasan wisata Jumiang. Selama ini, masalah utamanya adalah akses menuju kawasan wisata yang masih jelek. Banyak area jalan utama yang berlubang dan entah sengaja dilakukan pembiaran. Hal ini sangat disayangkan, mengingat peluang pengembangan kawasan wisata edukasi berkelanjutan (sustainable edutourism) yang sangat tinggi. Pembukaan wahana dan atrkasi wisata baru merupakan investasi menjanjikan bagi para inevestor. Atraksi wisata yang beragam membuat wisatawan tertarik berkunjung dan kebersihan lingkungan yang selalu terjaga membuat wisatawan betah dan kembali berkunjung ke kawasan wisata Jumiang.

Strategi WO yang terakhir (W4W5-O2O3) adalah meningkatkan perbaikan infrastruktur dan jalan menuju lokasi wisata. Alternatif strategi ini adalah kombinasi kekuatan infrastruktur di lokasi wisata kurang stabil (W4), dan jalan menuju lokasi yang masih rusak ringan dan berat sebagian (W5), dengan faktor peluang masih ada beberapa 
lahan untuk pengembangan $(\mathrm{O} 2)$ dan peluang mempunyai respon positif dari masyarakat (O3). Strategi ini bertujuan untuk mengatasi permasalahan utama yang dihadapi kawasan wisata Jumiang, yakni banyaknya sarana dan infrastruktur yang belum dikatakan layak untuk kawasan wisata andalan Kabupaten Pamekasan. Perbaikan jalan dengan memanfaatkan lahan yang masih tersedia dan bantuan dari pemerintah kabupaten adalah salah satu hal yang sangat perlu dilakukan. Tanpa akses yang baik, sarana dan prasarana yang mumpuni, dan dukungan dari stakeholder, pengembangan wisata Jumiang akan sulit untuk dicapai. Padahal dukungan dari masyrakat sudah sangat nyata. Salah satunya adalah semangatnya para anggota Pok-Darwis dan kelompok tani rumput laut yang sepakat untuk membangun kawasan wisata edukasi yang berkelanjutan (sustainable edustourism).

\section{Strategi Weakness - Threats (WT)}

Strategi ini merupakan perpaduan dari faktor kelemahan serta ancaman yang dimiliki. Alternatif strategi ini bertujuan untuk meminimalisir kelemahan sekaligus ancaman yang dimiliki. Tindakan ini diharapkan dapat meningkatkan jumlah kunjungan wisatawan ke Kawasan Wisata Jumiang. Strategi WT yang pertama (W1T1) adalah renovasi tata letak wisata lebih kreatif daripada wisata lain agar unik. Strategi ini merupakan perpaduan dari beberapa faktor kelemahan yaitu tata letak destinasi wisata belum rapi (W1) dan adamya wisata sejenis di dalam satu kabupaten (T1). Strategi ini bertujuan untuk menjadi pemenang di antara sekian desinasi wisata yang ada di Kabupaten Pamekasan. Seperti yang diketahui bahwa kawasan wisata Jumiang adalah salah stau destinasi wisata unggulan di Kabupaten Pamekasan. Hanya saja, jumlah kunjungan berkurang krena dianggap wisata jadul dan tidak mengikuti perkembangan tren wisata 'kekinian'. Salah satu solusinya adalah dengan memperbaiki tata letak wisata sehingga lebih menraik wisatawan. Berbagai atraksi wisata perlu ditambah, sehingga jumlah kunjungan juga dapat bertambah.

Strategi WT yang kedua (WT2) adalah membuat peraturan khusus tentang kebersihan (W2T2T3). Alternatif strategi ini merupakan kebersihan lingkungan kurang optimal (W2) dengan faktor ancaman yaitu regulasi setempat belum terintegrasi dengan baik (T2) dan manajemen Pok-Darwis yang masih tidak stabil (T3). Strategi ini bertujuan untuk mendukung strategi W2O3. Strategi ini bertujuan untuk memperbaiki 
kebersihan lingkungan di sepanjang kawasan wisata Jumiang yang memang sangat mengganggu pemandangan. Regulasi yang ketat tentang kebersihan lingkungan diharapkan dapat memberikan stimulus yang psoitif, baik kepada wisatawan, anggota Pok-Darwis, dan masyarakat sekitar. Sehingga kesan positif terhadap kawasan wisata Jumiang dapat meningkat.

Strategi WT yang kedua (W3W4W5-T2T3) adalah meningkatkan sarana prasarana, memperbaiki infastruktur dengan regulasi yamg baik melalui manajeman Pok-Darwis yang baik pula. Alternatif strategi ini merupakan kombinasi faktor kelemahan sarana dan prasana di dalam kurang memadai (W3), infrastruktur di lokasi wisata kurang stabil (W4), dan jalan menjuju lokasi yang masih rusak ringan dan berat sebagian (W5) dengan dengan faktor ancaman yaitu regulasi setempat belum terintegrasi dengan baik (T2) dan manajemen Pok-Darwis yang masih tidak stabil (T3). Strategi ini bertujuan untuk meningkatkan kunjungan wisatawan dengan cara memperbaiki sekaligus meningkatkan kualitas sarana, prasarana, infrastruktur, dan akses menuju kawasan wisata Jumiang. Perbaikan kualitas manajemen pengelolaan oleh Pok-Darwis juga menjadi komponen yang penting dalam pengembangan wisata Jumiang. Dukungan stakeholder pun tidak kalah pentingnya, sehingga perlu program kolaborasi antara pemerintah dan pengelola kawasan wisata Jumiang. 
Tabel 2 Analisis Strengh Weakness Opportunities Threats (SWOT)

\begin{tabular}{|c|c|c|}
\hline Faktor Eksternal & Peluang (Opportunity) & Ancaman (Threat) \\
\hline & $\begin{array}{l}\text { Berpeluang Menjadi Destinasi } \\
\text { Wisata Populer (O1) }\end{array}$ & $\begin{array}{l}\text { Adamya Wisata Sejenis Di } \\
\text { Dalam Satu Kabupaten (T1) }\end{array}$ \\
\hline Faktor Internal & $\begin{array}{l}\text { Masih Ada Beberapa Lahan } \\
\text { Ontuk Pengembangan (O2) }\end{array}$ & $\begin{array}{l}\text { Regulasi Setempat Belum } \\
\text { Terintegrasi Dengan Baik } \\
\text { (T2) }\end{array}$ \\
\hline & $\begin{array}{l}\text { Mempunyai Respon Positif } \\
\text { Dari Masyarakat (O3) }\end{array}$ & $\begin{array}{l}\text { Manajemen Pok-Darwis Yang } \\
\text { Masih Tidak Stabil (T3) }\end{array}$ \\
\hline Kekuatan (Strenght) & Strategi S-O & Stretegi S-T \\
\hline $\begin{array}{l}\text { Panorama Alam Yang Indah } \\
\text { Dengan Suasana Pantai (S1) }\end{array}$ & $\begin{array}{l}\text { Menambah Wahana Yang } \\
\text { Lebih Menarik Dengan } \\
\text { Panorama Yang Ada (S1,O2) }\end{array}$ & $\begin{array}{l}\text { Meningkatkan Kualitas } \\
\text { Wisata Dengan Keunikan } \\
\text { Panorama, Photospot Dan }\end{array}$ \\
\hline $\begin{array}{l}\text { Mempunyai Komoditas Khas } \\
\text { Yang Unik (S2) }\end{array}$ & $\begin{array}{l}\text { Mengembangkan Komoditas } \\
\text { Khas Menjadi Produk } \\
\text { Unggulan Kreatif (S2, O1) }\end{array}$ & $\begin{array}{l}\text { Komoditas Yang Dapat Di } \\
\text { Jadikan Sebagai Ikon Wisata } \\
(\mathrm{S} 1, \mathrm{~S} 2, \mathrm{~S} 3 \mathrm{~T} 1)\end{array}$ \\
\hline $\begin{array}{l}\text { Wahanan Photospot Yang } \\
\text { Menarik (S3) }\end{array}$ & $\begin{array}{l}\text { Meningktkan Kualitas } \\
\text { Wahana Photospot }(\mathrm{S} 3, \mathrm{O} 1)\end{array}$ & $\begin{array}{l}\text { Melakukan Komunikasi } \\
\text { Dengan Pemerintah Setempat }\end{array}$ \\
\hline $\begin{array}{l}\text { Jarak Yang Tidak Terlalu } \\
\text { Jauh Dari Jalan Raya (S4) }\end{array}$ & $\begin{array}{l}\text { Meningkatkan Promosi Yang } \\
\text { Lebih Menarik Bersama } \\
\text { Dengan Masayrakat }(\mathrm{S} 4, \mathrm{O} 3)\end{array}$ & $\begin{array}{l}\text { Untuk Mengintegrasi } \\
\text { Regulasi Yang Baik (S4, T2) }\end{array}$ \\
\hline $\begin{array}{l}\text { Merupakan Destinasi Yang } \\
\text { Bersejarah Lokal (S5) }\end{array}$ & $\begin{array}{l}\text { Memunculkan Sejarah Lokal } \\
\text { Pada Publik (S5, O1, O3) }\end{array}$ & $\begin{array}{l}\text { Memperbaiki Manajemen } \\
\text { Pok-Darwis Karena Masih } \\
\text { Berbudaya Lokal (S5, T3) }\end{array}$ \\
\hline Kelemahan (Weakness) & Strategi W-O & Stretegi W-T \\
\hline $\begin{array}{l}\text { Tata Letak Destinasi Wisata } \\
\text { Belum Rapi (W1) }\end{array}$ & $\begin{array}{l}\text { Redesign Tata Letak Wisata } \\
(\mathrm{W} 1, \mathrm{O} 2)\end{array}$ & $\begin{array}{l}\text { Renovasi Tataletak Wisata } \\
\text { Lebih Kreatif Dari Pada } \\
\text { Wisata Lain Agar Unik (W1, } \\
\text { T1) }\end{array}$ \\
\hline $\begin{array}{l}\text { Kebersihan Lingkungan } \\
\text { Kurang Optgimal (W2) }\end{array}$ & $\begin{array}{l}\text { Meningktkan Kebersihan } \\
\text { Lingkungan (W2, O3) }\end{array}$ & $\begin{array}{l}\text { Membuat Peraturan Khusus } \\
\text { Tantang Kebersihan (W2, T2, } \\
\text { T3) }\end{array}$ \\
\hline $\begin{array}{l}\text { Sarana Dan Prasana Di Dalam } \\
\text { Kurang Memadai (W3) }\end{array}$ & $\begin{array}{l}\text { Menambah Sarana Dan } \\
\text { Prasarana Yang Dibutuhkan } \\
\text { (W2, O1, O2) }\end{array}$ & $\begin{array}{l}\text { Meningktkan Sarana } \\
\text { Prasarana, Memperbaiki } \\
\text { Infastruktur Dengan Regulasi }\end{array}$ \\
\hline $\begin{array}{l}\text { Infrastruktur Di Lokasi } \\
\text { Wisata Kurang Stabil (W4) }\end{array}$ & $\begin{array}{l}\text { Meningkatkan Perbaikan } \\
\text { Infrastruktur Dan Jalan }\end{array}$ & $\begin{array}{l}\text { Yamg Baik Melalui } \\
\text { Manajeman Pok-Darwis Yang }\end{array}$ \\
\hline $\begin{array}{l}\text { Jalan Menjuju Lokasi Yang } \\
\text { Masih Rusak Ringan Dan } \\
\text { Berat Sebagian (W5) }\end{array}$ & $\begin{array}{l}\text { Menuju Okasi Wisata } \\
\text { (W4,W5 O2, O3) }\end{array}$ & $\begin{array}{l}\text { Baik Pula (W3, W4, W5, T2, } \\
\text { T3) }\end{array}$ \\
\hline
\end{tabular}

Sumber: Data primer, diolah (2019) 


\section{ANALISIS STRATEGI PENGEMBANGAN DENGAN ANALISIS SWOT \\ SEBAGAI KAWASAN WISATA UNGGULAN DAERAH \\ Yuyun Sasmita, Campina Illa Prihantini, Nursalam, Musoffan, dan Darwis}

\section{KESIMPULAN DAN SARAN}

Hasil kajian dan penelitian ini dapat menjadi dasar dan bahan pertimbangan dalam pengembangan wisata edukasi yang berkelanjutan (sustainable edutourism) di Kabupaten Pamekasan, sehingga masyarakat dapat lebih mandiri dalam kehidupan ekonomi..

\section{DAFTAR PUSTAKA}

[BPS] Badan Pusat Statistik. 2018. Kabupaten Pamekasan Dalam Angka 2018. Tersedia pada: http://pamekasankab.bps.go.id/publication/.

[BPS] Badan Pusat Statistik. 2018. Kecamatan Pademawu Dalam Angka 2018. Tersedia pada: http://pamekasankab.bps.go.id/publication/.

Umam NC. 2015. Analisis Kelembagaan Dan Strategi Pengembangan Wisata Pantai Pasir PutihMalikan (Papuma) Jember, Jawa Timur [Skripsi]. Bogor (ID): Institut Pertanian Bogor.

Hafidian dan Suprihardjo, 2013, Pengembangan Kawasan Wisata Pesisir Talang Siring di Kabupaten Pamekasan, Jurnal Teknik POMITS, Vol. 2(2), ISSN: 2337-3539.

Romadhon A. 2017. Penilaian Daya Dukung Pulau Pulau Kecil Bagi Wisata. Bangkalan. UTM Press.

Rangkuti. 2004. Analisis SWOT Teknik Membedah Kasus Bisnis. Jakarta. PT. Gramedia Pustaka Utama.

Simanjuntak dkk. 2016. Analisis Kelayakan Dan SWOT Objek Wisata Pemandian Alam Taman Rekreasi Gotong Royong Indah Di Desa Hulu, Kecamatan Pancurbatu, Kabupaten Deli Serdang, Provinsi Sumatera Utara. Jurnal USU. Vol 5(1).

Yoeti OA. 2010. Dasar-dasar Pengertian Hospitaliti dan Pariwisata. Bandung (ID). P.T. Alumni Bandung.

Prihantini CI dan Lutfiyanto. 2019. Pemberdayaan Kelompok Sadar Wisata (Pok-Darwis) Sebagai Penggerak Kemajuan Wisata Edukasi Jumiang. Jurnal Ethos. 7(2) : 228-235.

Prihantini CI dan Lutfiyanto. 2019. Analisis Persepsi Wisatawan Terhadap Kualitas Atraksi Dan Fasilitas Wisata Di Kawasan Wisata Jumiang, Kabupaten Pamekasan. Prosiding SEMNASDAL (Seminar Nasional Sumberdaya Lokal) II. 39-47.

Prihantini CI dan Lutfiyanto. 2020. Persepsi Karyawan Terhadap Kualitas Kelembagaan Kawasan Wisata Jumiang, Kabupaten Pamekasan. Jurnal Penelitian Sosial dan Ekonomi Kehutanan. 17(3) : 177-192.

Saghaei M, Leila F, Mohammad RS. 2012. Strategic planning for a lubricant manufacturing company using SWOT analysis, QSPM model (one of the Top companies of Iranian Oil, Gas and Petrochemical Products Exporters' Association). Australian journal of business and management research. 1(10) : 18-24.

Susdiyanti T, Humaira L, dan Supriono B. 2017. Analisis Pengembangan Program CSR Pengelolaan Taman Nasional Cianjur Taman Nasional Gunung Gede Pangrango. Jurnal Ethos. 5(1) : 42-47. 